\title{
The holiday carbon footprint in tourism education: Learning from practice and experience
}

\author{
La huella de carbono de las vacaciones en la enseñanza de turismo: \\ Aprendiendo desde la práctica y la experiencia
}

\author{
Bas Amelung $^{1^{*}}$ (1D \\ Eke Eijgelaar $^{2}$ (iD
}

\begin{abstract}
Tourism is on course to thwart humanity's efforts to reach a zero carbon economy because of its high growth rates and carbon intensity. To get out of its carbon predicament, the tourism sector needs professionals with carbon literacy and carbon capability. Providing future professionals in the full spectrum of tourism-related study programmes with the necessary knowledge and skills is essential. This article reports on ten years of experience at a BSc tourism programme with a carbon footprint exercise in which students calculate the carbon footprint of their latest holiday, compare their results with others and reflect on options to reduce emissions. Before they start, the students are provided with a handout with emission factors, a brief introduction and a sample calculation. The carbon footprints usually differ by a factor of 20 to 30 between the highest and lowest. Distance, transport mode and length of stay are almost automatically identified as the main causes, and as the main keys for drastically reducing emissions. The link to the students' own experience makes the exercise effective, the group comparison makes it fun. As the exercise requires no prior knowledge and is suitable for almost any group size, it can be integrated into almost any tourism-related study programme.
\end{abstract}

Keywords: holiday carbon footprint; tourism; education; carbon literacy; carbon capability; mitigation.

\section{Resumen}

El turismo está condicionando los esfuerzos para alcanzar una economía baja en carbono debido a sus elevadas tasas de crecimiento y su intensidad en la emisión de carbono. Para afrontar esta situación, el sector turístico necesita profesionales con conocimientos en la huella de carbono y la capacidad de reducir la emisión de carbono. Es esencial proporcionar a los futuros profesionales los conocimientos y habilidades necesarios en todos los programas de estudio relacionados con el turismo. Este artículo presenta un ejercicio sobre la huella de carbono en el que los estudiantes calculan la huella de carbono de sus últimas vacaciones, comparan sus resultados con los compañeros y reflexionan sobre las opciones para reducir las emisiones. Los estudiantes reciben un folleto guía con factores de emisión de carbono y, después de una breve introducción y un ejemplo de cálculo, calculan su huella de carbono de las últimas vacaciones. Las huellas de carbono tienden a diferir en un factor de 20 a 30 entre el más alto y el más bajo. La distancia recorrida, el modo de transporte y la duración de la estancia se identifican casi automáticamente como las principales causas y factores clave para reducir drásticamente las emisiones. Debido a que el ejercicio se relaciona con la propia experiencia de los estudiantes, las ideas se contraponen y la

1 Environmental Systems Analysis group, Wageningen University, Wageningen, The Netherlands. bas.amelung@wur.nl. *Corresponding author

2 Breda University of Applied Sciences, Breda, The Netherlands. eijgelaar.e@buas.nl 
comparación grupal añade diversión al análisis. Como el ejercicio no requiere de conocimientos previos y es adecuado para casi cualquier tamaño de grupo, puede integrarse en cualquier programa de estudio relacionado con el turismo.

Palabras clave: huella de carbono de vacaciones; turismo; educación; conocimientos de carbono; capacidad de carbono; mitigación.

\section{Introduction}

Climate change poses a grave threat to humanity. In response to that threat, 174 countries and the European Union signed the so-called Paris agreement in 2015 (UNFCCC, 2015). The Paris agreement aims to keep the increase in global temperature to below 2 degrees above pre-industrial levels, and aspires to keeping it below 1.5 degrees. These aims imply maximum available global carbon budgets for the entire period between the Industrial Revolution and today. At current emission rates, the budget associated with the 1.5 degree target will be depleted by 2027, the 2.0 degree budget by 2045. Little time is therefore left to convert our societies into low-carbon or zero-carbon societies; drastic cuts in emissions are required.

Tourism makes a substantial contribution to greenhouse gas emissions. More than a decade ago, tourism already caused an estimated 5\% of global greenhouse gas emissions (UNWTO-UNEP-WMO, 2008). This share has likely gone up since then, because most trends in tourism point to higher, not lower, emissions:

- More and more people participate in tourism as they acquire the opportunities and financial means to do so. Tourism trip numbers are increasing dramatically. International arrivals are expected to grow from 1.4 billion in 2018 (UNWTO, 2019) to 1.8 billion in 2030 (UNWTO, 2011), domestic tourism trips from 8.8 billion in 2016 to 15.6 billion in 2030 (UNWTO-ITF, 2019);

- The distances that people travel are increasing, as tourists travel internationally and intercontinentally more often. Peeters (2017) expects average one-way tourism travel distances to nearly double between 2015 (1050 km) and $2100(2050 \mathrm{~km})$;

- People increasingly take multiple shorter trips throughout the year rather than one long summer holiday;

- Tourists increasingly prefer flying over driving or taking a bus, train or bicycle. The share of air travel of international trips has been growing steadily and is projected to reach $61 \%$ in 2030 (UNWTO-ITF, 2019);

- The standard of luxury that tourists demand is increasing.

Because of these and other trends, Gössling and Peeters (2015) estimate tourism emissions to double between 2010 and 2032. More recently, Peeters (2017) assessed the long term development of tourism's carbon footprint and forecast an increase by a factor 4.6 between 2015 and 2100 . Were this forecast to materialise, global tourism, and particularly its aviation component, would singlehandedly wreck the Paris agreement, regardless of the performance of the rest of society.

With a share of $75 \%$, transportation makes the largest contribution to global tourism emissions, followed by accommodation (21\%) and activities (4\%). Individually, air (40\%) and car transport (32\%) are the largest emission components (UNWTO-UNEP-WMO, 2008). In particular the role of air travel is worrying, since technical improvements are not nearly enough to offset volume growth, let alone drastically reduce total emissions. Whereas electrification is an established technology and a feasible option for land-based transport, it is not a realistic option for air travel in the next few decades, and afterwards it will be too late (see e.g. Peeters, Higham, Kutzner, Cohen, \& Gössling, 2016). Fuel cells may be a more promising technology, but developing it into a commercially viable alternative will take time, after which aircraft will have to be retrofitted. A category of off-the-shelf technologies that seems readily available is power-to-fuel technology, in which kerosene or other fuels are synthetically produced from carbon dioxide $\left(\mathrm{CO}_{2}\right)$ and water $\left(\mathrm{H}_{2} \mathrm{O}\right)$. To produce this synthetic kerosene, $\mathrm{CO}_{2}$ is taken from the air and the same amount is released when the kerosene is burned, to that the process is carbon neutral. No technical adjustments are needed in the aircraft to use the fuel. The main downside of using synthetic kerosene is price. Barring technological solutions, the only way to reduce emissions is by limiting demand, i.e. by flying less (Peeters, Higham, Cohen, Eijgelaar, \& Gössling, 2019). The unfolding COVID-19 crisis shows how effective demand reductions are in lowering emissions from aviation: according to Le Quéré et al. (2020), $\mathrm{CO}_{2}$ emissions from aviation in April 2020 were 60\% lower compared to April 2019. 
With emissions going sharply up and the carbon budget rapidly depleting, the tourism industry faces an epic challenge. To have any hope of meeting this challenge, a joint effort by all categories of tourism stakeholders is required. To ramp up the future professionals' awareness and their ability to take action, integrating tourism's carbon predicament into the whole spectrum of tourism-related study programmes is essential. In this article we present a carbon footprint assignment that contributes to this goal in an effective and fun manner.

The article is organised as follows. In the next section, we present the background and learning objectives of the course in which we have used our carbon footprint exercise. The subsequent section provides details of the exercise and the ways in which it can be executed. In the discussion we reflect on the strengths and weaknesses of the exercise, and on the extent to which it helps to achieve the learning objectives. Finally, we draw conclusions about how the exercise can help address tourism's formidable climate challenge.

\section{Methodology}

\subsection{The carbon footprint exercise and its educational context}

The emissions from tourism are one of the topics addressed in the Environment \& Tourism course (ENT; course code ESA-11306), a first-year course in the academic BSc Tourism program, a joint degree program of Wageningen University and Breda University of Applied Sciences that has drawn between 20 and 50 new students per year since its start in 2010. ENT addresses the interactions between tourism and a range of global environmental issues, in particular climate change, biodiversity loss, water scarcity, and land-use change. The course uses the concept of the Anthropocene as its backdrop and the Planetary Boundaries framework (Steffen et al., 2015) as a structuring device (for a discussion on the role of tourism within these concepts, see Eijgelaar, Amelung, \& Peeters, 2016). The climate change topic is taught in two parts: the first part covers the science of climate change, the second part covers the links to tourism. The tourism part pays attention to both impacts on tourism (impacts and adaptation) and impacts of tourism (emissions). Two learning objectives related to the emissions aspect are for students to be able to 1. "reproduce the key components in tourism emissions and the factors most responsible for tourism emission growth" and 2. "explain and critically reflect on the options for mitigation in tourism." To help achieve these two learning objectives, we have developed a Carbon Footprint (CF) exercise that we have used and refined over the past 10 years.

The CF exercise works towards achieving the learning outcomes in two ways: by increasing students' 'carbon literacy', i.e. their understanding of the carbon problem, and by working on their 'carbon capabilities', i.e. their "ability to make informed judgments and to take effective decisions regarding the use and management of carbon" (Whitmarsh, O’Neill, Seyfang, \& Lorenzoni, 2009, p. 2). Whitmarsh et al. (2011) identify three core dimensions of carbon capability, and particularly the first two are addressed by ENT: (1) decision-making (knowledge, skills, motivations and judgements), (2) individual behaviour or 'practices' (e.g., own travel behaviour), and (3) broader engagement with systems of provision and governance. Carbon dioxide currently receives much societal and political attention, and policy is already developed for it. Awareness of concepts like the carbon footprint and the use of carbon calculators can assist in making carbon and climate change more personally relevant (Whitmarsh, Seyfang, \& O'Neill, 2011). The carbon footprint (Wiedmann $\&$ Minx, 2007) has been accepted as a legitimate indicator for calculating environmental impacts by a continuously increasing group of stakeholders, both inside and outside the tourism industry. Carbon footprints have also been used in education. Ribchester, Hunt, and Alexander (2009), for example, tested an experimental carbon footprint calculator with students while on a field trip; Fauville, Lantz-Andersson, Mäkitalo, Dupont, and Säljö (2016) had students around the world use an online carbon footprint calculator; and Edstrand (2016) reports on the use of a carbon footprint calculator by Swedish upper secondary school pupils. We have found no published studies on applications specifically tailored to tourism study programmes.

Our CF assignment has three main objectives: 1 . To allow students to practice with carbon footprint calculations; 2 . To provide students with a very personalized context to help them interpret information about emissions statistics; and 3. To help students get a better feel for the relative importance of a variety of factors determining tourism emissions.

In a brief lecture before the assignment we explain that emissions can be calculated by multiplying volume by an emission factor. The term 'volume' refers to the number of units of activity, for example 
the number of passenger kilometres in the case of transport or the number of guest-nights in the case of accommodation. The term 'emission factor' refers to the amount of emissions per unit of activity, for example the amount of $\mathrm{CO}_{2}$ emitted per passenger kilometre or per guest-night. We also explain that the exercise neither includes the indirect CF nor food and shopping. Food and shopping are actions that people also pursue at home to some extent, and including them makes calculations unnecessarily complex. Including the indirect CF is even more complex. The indirect $\mathrm{CF}$ measures the $\mathrm{CO}_{2}$ emissions caused by the production of cars, airplanes, kerosene, et cetera, and thus considers the entire lifecycle (see Wiedmann $\&$ Minx, 2007). To keep the exercise manageable for us and relatable for the students, it only considers the direct CF, which includes the $\mathrm{CO}_{2}$ emissions caused by the operation of cars, airplanes, hotels, etc.

\subsection{Implementing the carbon footprint exercise}

The CF assignment's core activity for students is to calculate the carbon footprint of their latest holiday trip, including transport, accommodation and activities. In doing so, they apply the key concepts of 'volume' and 'emission factor' that they have been introduced to before. Key emission factors are provided to the students by means of a handout. This hand out contains 26 default emission factors for transport, such as short-, medium- and long-haul air travel, several car types, and coach and train. It further contains 10 default emission factors for accommodation types, including hotels, apartments and camp sites, plus a link to www.bookdifferent.com, which provides model-based carbon footprints for some 1 million accommodations all over the world. Finally, emission factors for 17 energy-intensive activities are provided. The information on the handout is based on the best available literature (Eijgelaar, Thaper, \& Peeters, 2010; OECD/IEA \& UIC, 2013; Peeters, Szimba, \& Duijnisveld, 2007; UNWTOUNEP-WMO, 2008; amongst others), most of it gathered for long-standing work on tourism carbon footprints at Breda University of Applied Sciences (e.g. Eijgelaar, Neelis, Peeters, de Bruijn, \& Dirven, 2020). As this large body of work shows, emission factors may vary widely between types of aircraft, cars and hotels, but taking these variations into account would greatly complicate the calculations, hardly add to the learning experience, and make the handout unwieldy. The purpose of the handout is therefore to provide concise but meaningful information.

The students themselves contribute volume information related to accommodation (length of stay) and activities (types of activities performed). Transport-related volumes are expressed as distances travelled. Since students do not tend to have this information readily available, we provide them with various sources of information. First of all, the handout contains a table with return distances between the capital of The Netherlands (Amsterdam) and a long list of centrally located cities in other countries. Since the majority of BTO students are based in the Netherlands and also start and end their holidays there, this is a suitable route for many. To those originating from other countries and for those interested in getting a more precise estimate, we suggest using the great circle distance mapper gc.kls2.com for flights and Google Maps for road trips.

After distributing the handout, we demonstrate to students how to go about doing the calculations by taking on a hypothetical example: suppose we want to calculate the carbon footprint for each member of a family of four that takes a city trip from Amsterdam to Florence by car, spending 10 nights in a holiday home and taking one motorised boat trip as an activity. As per the handout, the transport volume equals $2330 \mathrm{~km}$ : the $2118 \mathrm{~km}$ great circle return distance, multiplied by a 'diversion factor' of 1.1 to account for the fact that the travel path taken between origin and destination is almost never a straight line. The emission factor for an average car is $0.184 \mathrm{~kg}$ of $\mathrm{CO}_{2}$ per vehicle kilometre, so that total car emissions are $428.7 \mathrm{~kg}$ of $\mathrm{CO}_{2}$, or $107 \mathrm{~kg}$ per person. The 10-day stay in the holiday home results in $159 \mathrm{~kg}$ of $\mathrm{CO}_{2}$ emissions per person; the boat trip adds another $15 \mathrm{~kg}$ of $\mathrm{CO}_{2}$ per person. All in all, the estimated total carbon footprint for the trip is $281 \mathrm{~kg}$ of $\mathrm{CO}_{2}$ per person, or $28.1 \mathrm{~kg}$ per person per trip day.

\section{Results}

In our experience over the last 10 years, the instructions and sample calculation provide students with enough information and confidence to start calculating the carbon footprint of their latest holiday trip. The students are asked to follow the example of the sample calculation and first calculate the carbon footprints of transportation, accommodation and activities separately, before adding them up. They are given a paper form (see Appendix 1) to write down their answers. As the students engage with the methods 
and numbers, questions for clarification almost always emerge. Recurring categories of questions relate to 1) multi-stage trips; 2) combinations of multiple transport modes; 3) local transportation; and 4) types of accommodation and activities that are not on the handout.

Regarding categories 1 and 2: some students use multiple modes of transportation to travel to their holiday destination, or they make a tour rather than a round trip to a destination, and struggle with the implications for their carbon footprint calculations. Our general response to this type of questions is that the carbon footprint of each of these stages should be calculated separately and then added; separate legs of a flight should also be calculated individually, if possible, as a short-haul distance has a much higher emission factor than a long-haul one. For long trips with many stages, this can be a time-consuming process. The student can also reconsider and pick another holiday for the exercise.

Some students take special interest in the observation that they do not only use transportation to travel to and from their destination(s), but also within the destination(s): local buses, trams, trains, rental cars, taxis etc. (category 3 ). If the available amount of time is very limited, we advise students to disregard local transport, unless the mileage involved is very high or air transport is involved. If time is less limited, we encourage students to explore their interest in local transport further. A final category (4) of questions relates to the incompleteness of the handout. While a range of accommodations are listed, there are almost always students who have used other types, such as bed\&breakfasts or motels. Similar issues can occur for activities. The general advice we give to students is to pick the option on the handout that they think is closest to the one they actually used.

Over the years, we have employed a variety of techniques to report back on the individual calculations. One of them is to ask a random student for their calculated carbon footprint, then ask if anyone has a higher number, pick a random one from those and so on, until the highest outcome is found. The same approach can be used to identify the lowest outcome. Typically, the highest outcome is very much higher than the lowest outcome, often a factor 10 to sometimes 30. The highest and lowest carbon footprints and their transport, accommodation and activities components are subsequently noted down on a flipchart, both the total amounts for the entire holiday and the average amounts per day. The numbers on the flipchart act as the start of a plenary discussion about the factors that may cause the large differences in carbon footprint. Distance, transport modes, flying and luxury automatically emerge from the discussions as key factors. The per-day values also help to pay attention to length of stay. Students find out that taking fewer but longer holidays often reduces the overall carbon footprint, because the transport component is so dominant.

While the 'any higher bids?' approach works well to open up the discussion, a downside is that all attention is focused on the extreme cases: the highest and the lowest carbon footprints. The other students may feel less interested or are left to wonder whether these extremes are outliers and how their own carbon footprint fits in. Over the years, we have therefore experimented with more engaging approaches, in which all individual calculations are accounted for. A low-tech approach is to ask students to hand in their paper forms and break for coffee. The teaching team then has time to manually enter the results in a spreadsheet and sort them. After the break, the full range of results can then be shown, so that each student can see how they score relative to their peers. Figures 1, 2 and 3 show examples of how outcomes for total emissions, emissions per day and share of transport emissions can be represented. In the Figures, each column represents one of the 36 participating students, labelled S1 to S36 to allow for the tracing of students between the three Figures. In class, the columns are labelled by name. This individualized approach often gives rise to some commotion as students evaluate their position in the range and may boast about their low (or high) carbon footprint or joke about others' performance. Soon afterwards, a discussion unfolds along the same lines as described above.

To illustrate what such a discussion might entail, let's have a brief look at Figures 1, 2 and 3. Student S11 - having travelled to Australia - has by far the highest total holiday emissions, but 'only' ranks 10th for per day emissions due to the long length (42 days) of the trip. In contrast, students S1 and S21, both on short (7-and 6-day respectively) trips to Caribbean islands, have very high per day emissions, but only rank midfield regarding total emissions. Because of the combination of a long flight, short stays and small islands, these same two students lead the pack in terms of the transport share of total holiday emissions. After the comparison between students, we further enrich the discussion by comparing the students' performance with that of Dutch holidaymakers in general, as reported by Breda University of Applied Sciences. The average carbon footprint of Dutch holidaymakers is $234 \mathrm{~kg}$ of $\mathrm{CO}_{2}$ for domestic holidays and $825 \mathrm{~kg}$ of $\mathrm{CO}_{2}$ for outbound long (i.e. 5-day+) holiday, or 22 and $62 \mathrm{~kg}$ respectively on a per-day basis (Eijgelaar et al., 2020). Typically, two-thirds of the students have higher carbon footprints than these averages. 
Figure 1. Total holiday carbon footprints (in $\mathrm{kg}$ of $\mathrm{CO}_{2}$ ) for each participating student in the 2019-2020 Environment \& Tourism class, sorted largest to smallest

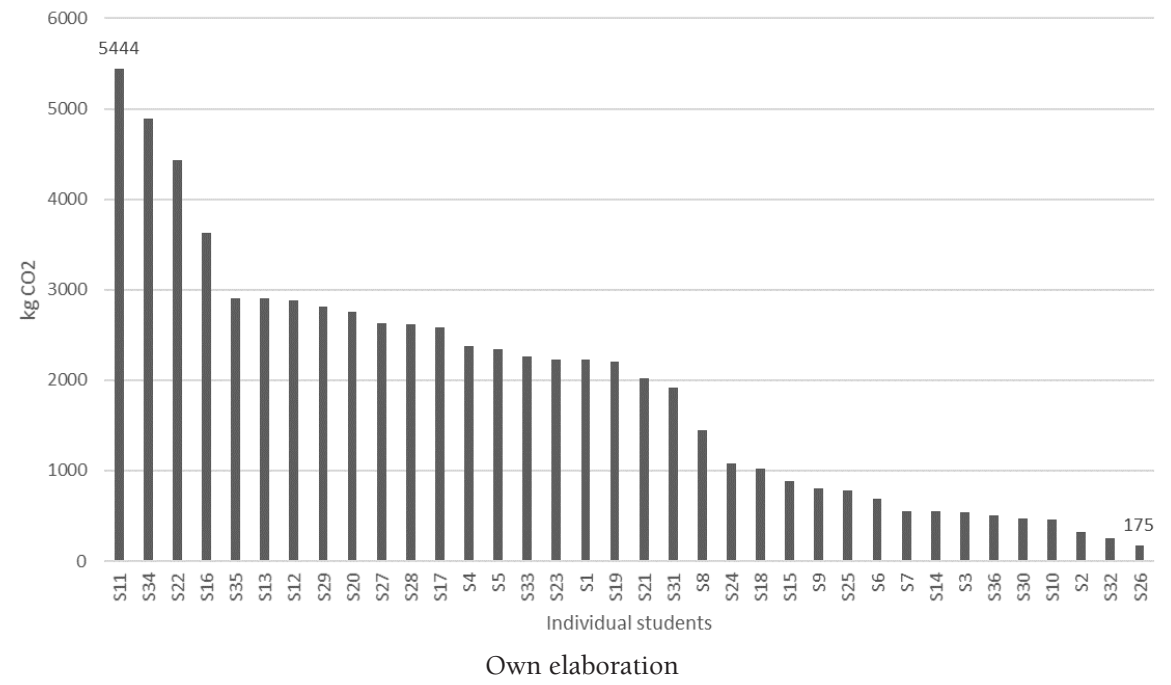

Figure 2. Holiday carbon footprints per day (in $\mathrm{kg}$ of $\mathrm{CO}_{2}$ ) for each participating student in the 2019-2020 Environment \& Tourism class, sorted largest to smallest

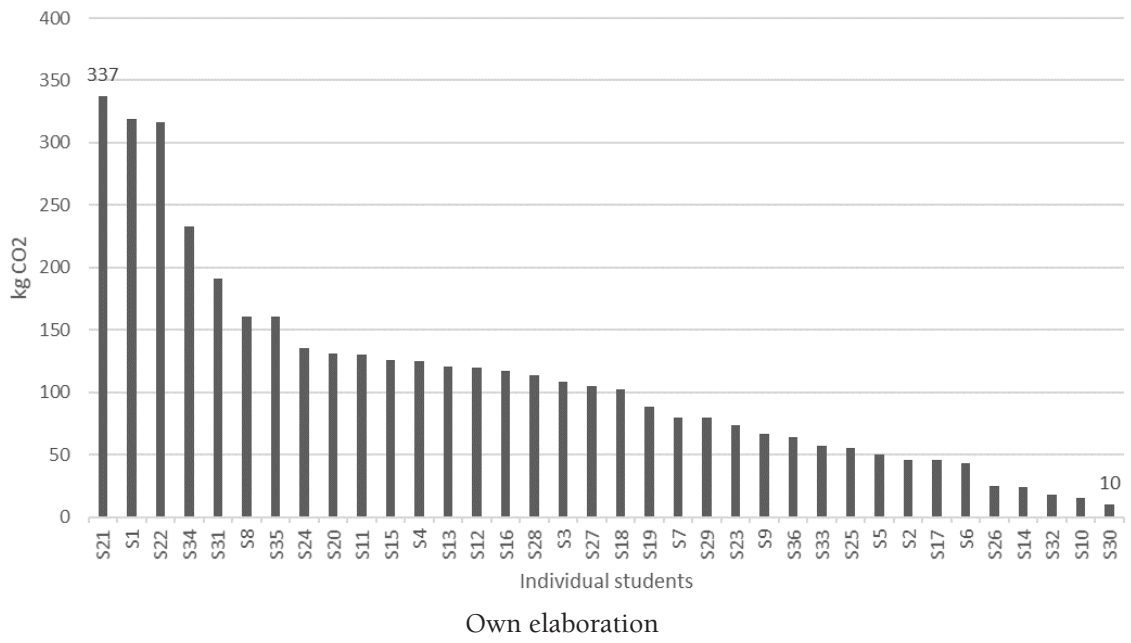

Figure 3. Transport share of total holiday carbon footprints for each student in the 2019-2020 Environment \& Tourism class, sorted largest to smallest

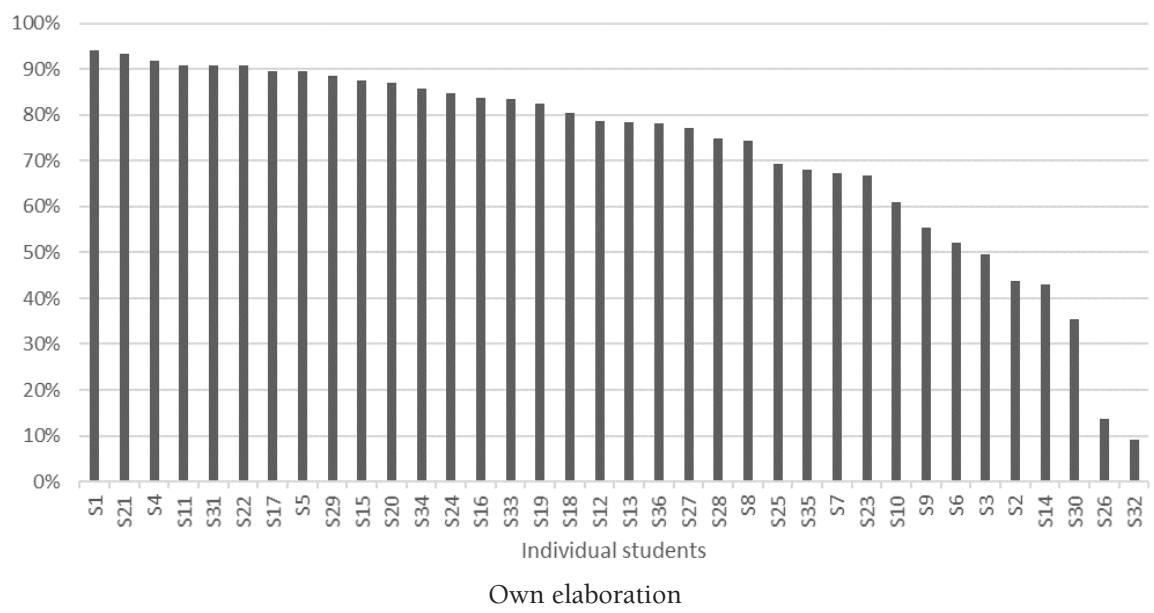


A more advanced variety of the same approach is to ask the students to fill out their numbers in an online spreadsheet or to submit them through Socrative or another online interactive system. Whereas this approach may appear more efficient at first sight, considerable data cleaning is usually required, for example because students enter non-numerical data (e.g. ' $\mathrm{kg}$ ') or use the wrong decimal separator (e.g. the Dutch ',' instead of the American '.') or report values that cannot be correct. Automatic checks may help address many of these issues, but in our course, we have not implemented such checks yet.

If time allows, a useful follow-up to the carbon footprint calculations and discussion is an exploration of the options for emissions mitigation. In our class, this extension is dubbed 'pimp your holiday footprint'. The idea behind it is to consider the options for devising a holiday that is similar to the one actually taken but with a minimum of emissions. In this context, we often show students four photos of beach destinations. We tell them that one of them is in France, one in Thailand, one in Mexico and one in Greece, and ask the students to connect the right photo with the right country. The share of right answers is typically low or even zero, driving home the point that popular types of tourism destinations, such as beach destinations, may be highly interchangeable. This realisation opens up large opportunities for sharply reducing distances travelled, and thus emissions, while forgoing few, if any, of the original holiday's qualities. Greatly reducing distances travelled, in turn, opens up new opportunities for changing transport mode. While a Dutch tourist has little choice but to travel by airplane for a beach holiday in Thailand or Mexico, travelling to France can be easily accomplished by train, coach or car.

\section{Discussion}

Over the years, the carbon footprint assignment has proven to be a very effective exercise to achieve two of our key learning goals, that is: to make sure that after the course students are able to "reproduce the key components in tourism emissions and the factors most responsible for tourism emission growth" and "explain and critically reflect on the options for mitigation in tourism."

When we first developed and used the exercise in 2010, we were not aware of any carbon footprint exercises in higher education. Given the incorporation of climate change into all kinds of curricula, the use of such exercises is likely much more widespread today, probably also in tourism courses. The range of carbon accounting exercises for students of business programmes that can be found online, for example, are evidence of the mainstreaming of carbon-related assignments, even though it is worth noting that these particular exercises are not about individual footprints. The body of academic literature on the topic is growing, but remains small.

The studies on the use of individual footprints that are available reach remarkably similar conclusions, which also resonate with ours. Cordero, Todd, and Abellera (2008), for example, who ran an online ecological footprint quiz with meteorology students, report significant improvements in students' understanding of the connection between personal energy use and climate change. The authors suggest that the ecological footprint activity can serve as an "example of an effective curriculum design that provides a pathway for enhancing student understanding and possibly altering student behavior in a manner that promotes deeper learning" (Cordero et al., 2008, p. 871). Ribchester, Hunt, and Alexander (2009), who tested an experimental carbon footprint calculator with students on a field trip, hinted at possible long-term effects as students indicated to think more profoundly about future (consumption) choices. We also notice this when discussing results with students, but have not tested future travel behaviour. Fauville, Lantz-Andersson, Mäkitalo, Dupont, and Säljö (2016) found that students are not able to come up with a reasonable estimate of their own footprint by themselves, which corresponds to our own experience. They also found that students, after using an online carbon footprint calculator and discussing the results with their peers on an online forum, developed new modes of reasoning, for example on how to negotiate their contributions to the global consequences of their carbon footprint. When Edstrand (2016) let Swedish upper secondary school pupils use a carbon footprint calculator and then monitored the classroom discussions about the results, she found the exercise to support different ways of reasoning and arguing about the environmental impact of an individual. The exercise offered the pupils new possibilities of understanding climate change and the relationships with their own activities. Edstrand (2016) notes that the carbon footprint tool enables students to 'see' environmental aspects that they could otherwise not perceive. Collins, Galli, Patrizi, and Pulselli (2018) used the Global Footprint Networks' personal Ecological Footprint (EF) calculator with High School and postgraduate University 
students in Italy and the UK. Students ran their individual calculations and explored the consequences of their behaviour. Like in our own exercise, this calculator enabled students to debate the sustainability of consumption choices (here in the context of their everyday life). Many of these studies emphasize the eye-opening effect the footprint assignments have on students (Cordero et al., 2008; Fauville et al., 2016), something we also notice every time.

Our exercise directly connects to students' personal experience and, in a very natural and compelling way, leads students to conclude that distance, transport mode, length of stay and levels of luxury are the key determinants of holiday emissions. By comparing their own holiday choices with those of their peers, students also get a very real understanding of how much their own choices and behaviour matter. The importance of having such a discussion is also emphasized by the literature that we referred to above. In addition, the exercise provides students with a point of reference, which they can use to evaluate emissions statistics later on. With such a reference, information expressed in kilogrammes or tonnes of $\mathrm{CO}_{2}$ becomes much more meaningful.

The exercise also provides an excellent platform to address, either through discussion or in a follow-up lecture, the main options for mitigation. By stipulating the main determinants of total holiday emissions, it also identifies the main candidates for emissions reduction. A discussion of the factor 'distance', for instance, may lead students to reflect on the interchangeability of destinations. Is a beach holiday in the Caribbean qualitatively different enough from one in the Mediterranean to justify the much larger carbon footprint that a Dutch tourist would cause?

The exercise can be modified or extended in multiple directions, according to any specific aspects the teacher may want to emphasize. Students can be asked, for example, to calculate the carbon footprints of all holiday trips they took during an entire year, to highlight the effect on emissions of taking multiple short trips rather than one or two longer ones. The exercise can also be extended to include food and shopping or even the indirect carbon footprint, but that would be very challenging. Courses that cover issues of environmental justice could also use the results for a discussion about carbon equity by comparing the students' holiday carbon footprint with available carbon budgets per person, according to various equity principles (Lange, Vogt, \& Ziegler, 2007).

Besides its effectiveness in reaching the learning outcomes, the exercise has major practical strengths. First of all, it is low-key and accessible: the exercise does not require any prior knowledge. A brief explanation and a quick demonstration of how to use the handout suffice, so that the exercise can be used with almost any kind of students. For instance, we have repeatedly done the exercise with prospective students attending the BTO programme's annual Open Day. Secondly, the exercise is highly scalable. It works with 10 students, but also with 100 students or more, provided that the results can be aggregated into an Excel sheet relatively quickly. Smaller groups may be conducive to more animated and profound discussions, while larger groups tend to show a greater diversity in results. Finally, and perhaps most importantly, the exercise is fun! Almost without exception, students are eager to learn about the carbon footprint of their own holidays. In addition, they tend to enjoy the social process of comparing their own results with those of others.

A potential downside of the carbon footprint exercise is that it is more time-consuming than a lecture on the same topic. The exercise and a lecture are hardly comparable, however; the learning associated with the exercise is much more profound. Whereas a lecture leads to knowledge transfer at best, the carbon footprint exercise goes far beyond that, providing students with a platform to 'experience and experiment' (Student, Lamers, \& Amelung, 2020), resulting in more profound insights and a clearer scope for action (Cordero et al., 2008). In other words, the exercise not only improves the students' carbon literacy, but also, and more importantly, their carbon capability.

\section{Conclusions}

In this paper, we proposed a carbon footprint exercise as an effective and fun tool to educate students about the epic challenge the tourism industry is facing with respect to reducing or even eliminating its $\mathrm{CO}_{2}$ emissions, and about the contributions the students can make to meet this challenge. The effectiveness of the exercise is rooted in its accessibility and simplicity, and in its connection to students' personal experience. By calculating the carbon footprint of their own most recent holiday, students find additional meaning in the numbers and connect to the topic on an emotional level. In addition, the personal results 
yield insights into the most promising options for mitigating emissions, so that students internalise their locus of control with respect to $\mathrm{CO}_{2}$ emission reduction and increase their carbon capabilities. The fun aspect of the exercise relates to the students' eagerness to learn something about themselves and compare their own performance with that of others. The scalability and simplicity of the exercise make it suitable for students of the whole spectrum of tourism-related study programmes. The exercise can therefore be instrumental in driving the joint effort by all groups of tourism stakeholders, required to get out of tourism's carbon predicament.

\section{Appendix 1}

Carbon Footprint Assignment, CBTO1ENT

Name:

Goal: Learn more about the carbon footprint (CF) of tourism and its components, by applying a carbon calculation.

Method: Calculate the carbon footprint of your main holiday in 2019, explore effective options for reducing the footprints, and reflect on the results. Use a calculator plus the hand-out with return distances and emission factors for holiday emissions. Fill in the table and submit the results in a GoogleForm.

Relevance/importance: Carbon footprint calculations and key (qualitative) insights from the assignment may be part of the exam material.

Time: about 1 hour

1. INDIVIDUAL ( 30 minutes)

Calculate the $\mathrm{CF}$ of your main holiday in 2019, by writing down the $\mathrm{CF}$ for each component (if you used several modes or flight-legs, or accommodations, note them separately). Also enter the CF per day.

\begin{tabular}{|c|c|c|c|c|c|c|}
\hline \multicolumn{2}{|c|}{ Holiday } & & & & & \\
\hline \multicolumn{3}{|l|}{ Destination: } & \multicolumn{4}{|c|}{ Length of stay: ................. days } \\
\hline Holiday component & Places / name & $\begin{array}{l}\text { Mode/ } \\
\text { type }\end{array}$ & $\begin{array}{l}\text { Total kms* } \\
\text { or nights }\end{array}$ & $\begin{array}{l}\text { Emission } \\
\text { factor }\end{array}$ & $\begin{array}{l}\text { Seat } \\
\text { occupancy }\end{array}$ & $\begin{array}{l}\text { kg CO} \\
\text { p.p. }\end{array}$ \\
\hline EXAMPLE & Ams-Paris return & Car diesel & 1200 & 0.177 & 3 & 70.8 \\
\hline EXAMPLE & Paris & Hotel & 6 & 20.6 & - & 123.6 \\
\hline \multicolumn{7}{|l|}{$\begin{array}{l}\text { Home/Destination } \\
\text { transport leg1 }\end{array}$} \\
\hline \multicolumn{7}{|l|}{$\begin{array}{l}\text { Home/Destination } \\
\text { transport leg2 }\end{array}$} \\
\hline \multicolumn{7}{|l|}{ Accommodation 1} \\
\hline \multicolumn{7}{|l|}{ Accommodation 2} \\
\hline \multicolumn{7}{|l|}{ Accommodation 3} \\
\hline \multicolumn{7}{|l|}{ Activities 1} \\
\hline \multicolumn{7}{|l|}{ Activities 2} \\
\hline \multicolumn{7}{|l|}{ Activities 3} \\
\hline \multicolumn{7}{|l|}{ Local transport 1} \\
\hline \multicolumn{7}{|l|}{ Local transport 2} \\
\hline \multicolumn{7}{|l|}{ Local transport 3} \\
\hline \multicolumn{7}{|l|}{ Total CF per person } \\
\hline CF p.p. per day & & & & & & \\
\hline
\end{tabular}

*don't forget diversion factor, if applicable

2. SUBMISSION

Enter your holiday footprint results in this GoogleForm.

3. PLENARY ( 15 minutes)

The results will be shown on the main screen. Discussion. What are your main insights from this assignment and the results? What surprised you the most, and why? Did this assignment give you an idea about the impact of tourism/holiday? 


\section{References}

Collins, A., Galli, A., Patrizi, N., \& Pulselli, F. M. (2018). Learning and teaching sustainability: The contribution of Ecological Footprint calculators. Journal of Cleaner Production, 174, 1000-1010. https://doi.org/10.1016/j.jclepro.2017.11.024

Cordero, E. C., Todd, A. M., \& Abellera, D. (2008). Climate Change Education and the Ecological Footprint. Bulletin of the American Meteorological Society, 89(6), 865-872. https://doi. org/10.1175/2007BAMS2432.1

Edstrand, E. (2016). Making the invisible visible: how students make use of carbon footprint calculator in environmental education. Learning, Media and Technology, 41(2), 416-436. https://doi.org/10.1080 /17439884.2015.1032976

Eijgelaar, E., Amelung, B., \& Peeters, P. (2016). Keeping tourism's future within a climatically safe operating space. In M. Gren \& E. H. Huijbens (Eds.), Tourism and the Anthropocene (pp. 17-33). Abingdon, UK: Routledge.

Eijgelaar, E., Neelis, I., Peeters, P., de Bruijn, K., \& Dirven, R. (2020). Travelling large in 2018: The carbon footprint of Dutch holidaymakers in 2018 and the development since 2002. Breda, The Netherlands: Breda University of Applied Sciences.

Eijgelaar, E., Thaper, C., \& Peeters, P. (2010). Antarctic cruise tourism: the paradoxes of ambassadorship, "last chance tourism" and GHG emissions. Journal of Sustainable Tourism, 18(3), 337-354. https://doi. org/10.1080/09669581003653534

Fauville, G., Lantz-Andersson, A., Mäkitalo, Å., Dupont, S., \& Säljö, R. (2016). The Carbon Footprint as a Mediating Tool in Students' Online Reasoning about Climate Change. In O. Erstad, K. Kumpulainen, Å. Mäkitalo, K. C. Schrøder, P. Pruulmann-Vengerfeldt, \& T. Jóhannsdóttir (Eds.), Learning across contexts in the knowledge society (pp. 179-201). Leiden, The Netherlands: Sense Publishers.

Gössling, S., \& Peeters, P. (2015). Assessing tourism's global environmental impact 1900-2050. Journal of Sustainable Tourism, 23(5), 639-659. https://doi.org/10.1080/09669582.2015.1008500

Lange, A., Vogt, C., \& Ziegler, A. (2007). On the importance of equity in international climate policy: An empirical analysis. Energy Economics, 29(3), 545-562. https://doi.org/10.1016/j.eneco.2006.09.002

OECD/IEA, \& UIC. (2013). Railway Handbook 2013: Energy Consumption and $\mathrm{CO}_{2}$ Emissions - Focus on Energy Mix. Retrieved from Paris, France:

Peeters, P. (2017). Tourism's impact on climate change and its mitigation challenges. How can tourism become 'climatically sustainable'? (PhD), TU Delft, Delft, Netherlands.

Peeters, P., Higham, J., Cohen, S., Eijgelaar, E., \& Gössling, S. (2019). Desirable tourism transport futures. Journal of Sustainable Tourism, 27(2), 173-188. https://doi.org/10.1080/09669582.2018.1477785

Peeters, P., Higham, J., Kutzner, D., Cohen, S., \& Gössling, S. (2016). Are technology myths stalling aviation climate policy? Transportation Research Part D: Transport and Environment, 44, 30-42. https:// doi.org/10.1016/j.trd.2016.02.004

Peeters, P., Szimba, E., \& Duijnisveld, M. (2007). Major environmental impacts of European tourist transport. Journal of Transport Geography, 15, 83-93. https://doi.org/10.1016/j.jtrangeo.2006.12.007

Ribchester, C., Hunt, T., \& Alexander, R. (2009). "How big's your engine, mate?" Encouraging active participation in ESD by assessing the carbon footprint of field work. Planet, 22(1), 27-33. https://doi. org/10.11120/plan.2009.00220027

Steffen, W., Richardson, K., Rockström, J., Cornell, S. E., Fetzer, I., Bennett, E. M., ... \& Sörlin, S. (2015). Planetary boundaries: Guiding human development on a changing planet. Science, 347(6223). https:// doi.org/10.1126/science.1259855

Student, J., Lamers, M., \& Amelung, B. (2020). A dynamic vulnerability approach for tourism destinations. Journal of Sustainable Tourism, 28(3), 475-496. https://doi.org/10.1080/09669582.2019.1682593

UNFCCC. (2015). Adoption of the Paris Agreement. Proposal by the president. Geneva, Switzerland: UNFCCC.

UNWTO-ITF. (2019). Transport-related $\mathrm{CO}_{2}$ emissions of the tourism sector - Modelling results. Madrid, Spain: UNWTO. 
UNWTO-UNEP-WMO. (2008). Climate Change and Tourism: Responding to Global Challenges. Madrid, Spain: UNWTO-UNEP.

UNWTO. (2011). Tourism Towards 2030 / Global Overview - Advance edition presented at UNWTO 19th General Assembly. Madrid, Spain: UNWTO.

UNWTO. (2019). International Tourist Arrivals by (Sub)region. UNWTO Tourism Barometer, 17(2), 4. https://doi.org/10.18111/wtobarometereng

Whitmarsh, L., O'Neill, S., Seyfang, G., \& Lorenzoni, I. (2009). Carbon Capability: what does it mean, how prevalent is it, and how can we promote it. Tyndall Working Paper, 132. Norwich, UK: Tyndall Centre for Climate Change Research.

Whitmarsh, L., Seyfang, G., \& O'Neill, S. (2011). Public engagement with carbon and climate change: To what extent is the public 'carbon capable'?. Global Environmental Change, 21(1), 56-65. https://doi. org/10.1016/j.gloenvcha.2010.07.011

Wiedmann, T., \& Minx, J. (2007). A Definition of 'Carbon Footprint' (Vol. Research Report 07-01). Durham, UK: ISA UK Research \& Consulting. 